\title{
Ibn Sīnā's Remarks on a Khwarizmian Sound*
}

\section{ADAM BENKATO}

\begin{abstract}
In his study of Arabic phonetics, Asbāb hudūt al-hurūf (The Causes of the Genesis of the Consonants), Ibn Sìnā briefly surveys some speech sounds found in languages other than Arabic, among them one particular to Khwarizmian, an Iranian language attested primarily in glosses to Arabic manuscripts of the 13th century. This study attempts to elucidate the sound Ibn Sina describes both through reference to his own system of phonetic terminology and through comparison with extant material in the Khwarizmian language.
\end{abstract}

Keywords: Khwarizmian; Middle Iranian; Arabic; Avicenna; Al-Biruni

The Khwarizmian language, belonging to the Iranian branch of the Indo-European family and spoken in the fertile delta of the Amu Darya river south of the Aral Sea, was long known to have existed only through the reports of the famed polymath Abū Rayhān al-Bīrūnī (d. I050). In one of his most important extant works, al-Ațār al-bāqiya 'an al-qurūn al-khāliya (Chronology), he discusses various calendrical terms, giving the names of the months, days, and lunar stations in Khwarizmian as he does for Arabic, Hebrew, Persian, Syriac, and Sogdian. ${ }^{1}$ In the same work, al-Bīrūnī also laments the Arab conquest of Khwarizm which led to the destruction of older institutions, especially to a loss of the knowledge of writing in

* It is a pleasure to offer this study to François de Blois, with whom I studied Khwarizmian some years ago, in honour of his incomparable scholarship at the intersections of Arabic and Iranian philology. For drawing my attention to the remarks of Ibn Sīna discussed herein and commenting helpfully on a draft of this paper, I thank Kevin Van Bladel.

${ }^{1}$ Sachau, Eduard, The Chronology of Ancient Nations (London, I879), pp. 57-58 and 223-228. The name of the region and the language have been rendered variously in works in European languages: "Chorasmian" and "Choresmian" are based on Greek Xop $\alpha \sigma \mu i \alpha$ while "Khwarezmian" is based on Persian خوارزم and "Khwarazmian" seems to be based on the Old Persian form (h)uvārazmiš. The Arabic form occurring in the extant textual sources is khuwârizm خُوارِزْم For consistency with the Arabic-language source material, I use Khwarizm/Khwarizmian throughout this piece. The name of the region itself is attested as Avestan as $x^{\nu}$ airizam (acc.sg.) in addition to Old Persian as (h) $u$ ārazmiš $<\mathrm{u}-\mathrm{v}-\mathrm{a}-\mathrm{r}-\mathrm{z}-\mathrm{m}^{\mathrm{i}}-\mathrm{i}-\mathrm{s}>$ (nom.sg.), which may be derived from *hwāra- "low" (as was already recognized by David MacKenzie ('Khwarazmian language and literature', in The Cambridge History of Iran Vol. III, Part 2 (I983), p. I244) plus *zm- (zero-grade of *zam- "land") with a likely meaning of "low-lands"-not unreasonable given the low elevation of the marshy (in antiquity) region south of the Aral Sea. 
the indigenous Khwarizmian script. ${ }^{2}$ As a Khwarizmian by birth, al-Bīrūn̄̄ was of course personally familiar with its history and customs. ${ }^{3}$ On the basis of a passage in another of his works, the Kitāb al-șaydana fì l-țibb (Pharmacology), it has been assumed that his native language was indeed Khwarizmian. ${ }^{4}$ In that work, al-Bīrūnī justifies his praise of Arabic as the scientific language par excellence by explaining that not only is Persian, which he also knows, unsuitable, but that moreover he has a mother tongue even less suitable for science, though he does not name it explicitly:

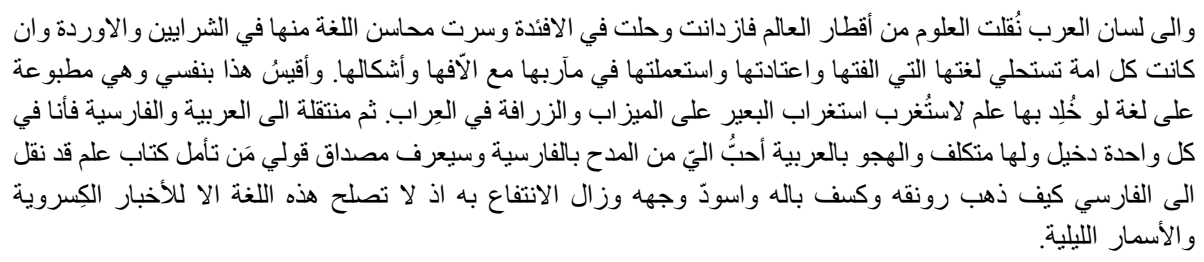

"From diverse corners of the world the sciences were transferred into Arabic, were embellished, inhabited in hearts, and the niceties of the language flowed through their arteries and veins, even though each nation prefers their language, which it is familiar with and used to and uses in fulfilling its needs with its peers and familiars. I measure this against my own self, for I was brought up in a language which, were science ever to be immortalized in it, it would be as astounding as a mule in a waterspout or a giraffe among thoroughbreds. Then I went over to Arabic and Persian, and am a stranger in each language and struggle in each one. But I would prefer insults in Arabic to praise in Persian! He who has ever engaged with a book of science translated into Persian will know the truth of my words - how its elegance disappeared, its sense darkened, its visage blackened, and its usefulness was voided. For this language (Persian) is only fit for reciting the legends of kings or bedtime stories". 5

Reports such as al-Bīrūnī's were already an indication that the Khwarizmian language continued to be spoken at least up until the turn of the first millennium-later in fact, than the other known Iranian languages of Central Asia, Sogdian and Bactrian, are attested in their respective homelands.

\footnotetext{
${ }^{2}$ Sachau, Chronology, 42. We now know that the pre-Islamic Khwarizmian writing system was derived from the Aramaic script, as were the scripts of most of the other Middle Iranian languages, see Vladimir A. Livshits, 'The Khwarezmian Calendar and the Eras of Ancient Chorasmia', Acta Antiqua Academiae Scientiarum Hungaricae I6 (I968), pp. 433-446 and more recently Pavel Lurje, 'Some New Readings of Chorasmian Inscriptions on Silver Vessels and Their Relevance to the Chorasmian Era', Ancient Civilizations from Scythia to Siberia 24, no. I-2 (2018), pp. 279-306. Some documents in the Aramaic-derived Khwarizmian script have been discovered, but all are very difficult to read and have yet to be successfully deciphered and edited in their entirety; a number of ossuaries with Khwarizmian inscriptions are a partial exception. This article will not deal with those sources.

${ }^{3} \mathrm{Al}-\mathrm{B} \bar{r} \mathbf{r} \bar{n} \overline{1}$ also composed a separate treatise on the political history of Khwarizm, Kitāb al-musāmara fi akhbār Khuwarizm (Telling Tales about the Affairs of Khwarizm) which is lost and now known only from quotations in other works.

${ }^{4}$ For example E. S. Kennedy, 'al-Biruni', in Dictionary of Scientic Biography, vol. 2 (I98 I), pp. I47-I 58.

${ }^{5}$ Emphasis and translation mine. The introduction to the Pharmacology was edited and translated into German from Arabic by Max Meyerhof ('Das Vorwort der Drogenkunde des Beruni', Quellen und Studien zur Geschichte der Naturwissenschaften 3 (1932), pp. I 57-208) while Hamarneh and Said (Sami K. Hamarneh \& Hakim Mohammad Said, Al-Biruni's Book on Pharmacy and Materia Medica, 2 vols. (Smithsonian Institution, printed under the auspices of the Hamdard National Foundation, Karachi, Pakistan, I973-I976)) provide a handwritten edition of the entire text with translation into English and a commentary. An updated and more legible edition would be a worthwhile endeavour, especially considering the difficulty of the numerous pharmacological terms in the various languages given in Arabic transcription. The passage quoted here is based on Meyerhof's edition, see Meyerhof, 'Das Vorwort der Drogenkunde des Beruni', p. 2 Io (German), p. 228 (Arabic), which has some irregularities. The Pharmacology was actually known only in its Persian version until Zeki Velidi Togan discovered the Arabic original in I926.
} 


\section{The Khwarizmian Sources}

However, nothing else was really known of Khwarizmian until a series of spectacular discoveries made by the Beshkiri scholar Zeki Velidi Togan (I890-1970) between the I920s and I940s, which revealed two groups of Khwarizmian source material written in a modified Arabic script and recorded in Arabic texts. ${ }^{6}$

One is comprised of Islamic legal texts in Arabic containing Khwarizmian sentences. Chronologically, the first of these is a compendium entitled Yatīmat al-dahr fi fatāwa 'ahl al- 'așr (The Matchless Pearl of the Age on the Fatwas of Contemporaries) composed by Muhammad 'Alā' al-Dīn al-Tarjumān̄̄ al-Khuwārizmī (d. I257), several manuscripts of which contain Khwarizmian sentences in Arabic script. ${ }^{7}$ Next comes a similar type of text entitled Qunyat al-munya li-tatmìm al-gunya (The Acquisition of that which is Desired for the Completion of the Sufficiency), compiled in the early ${ }^{\text {th }}{ }^{\text {th }}$ century by Najm al-Dīn al-Zāhidī al-Ghazmīn̄i (d. I260). ${ }^{8}$ The Qunya is itself a summary of a now-lost work entitled Munyat al-fuqahā' by the teacher of al-Ghazmīn̄in, Fakhr al-Dīn al-Qubaznī (known as Qāḍ̄ Badī'), the Qunya itself repeating much of the material of the Yatima probably via the Munya. Several manuscripts of the Qunya contain extensive text in Khwarizmian. Then, about a century later the Khwarizmian material of the Munya and the Qunya was gathered into an untitled compendium by yet another scholar of Khwarizmian origin, Jamāl al-Dīn al-'Imādī (d. ca. I354). This latter work, otherwise untitled, has been called the Risäla (Treatise). ${ }^{9}$

The Yatima / Qunya groups of texts give cases of Islamic law taken from real life in medieval Khwarizm, often including dialogue in Khwarizmian and a discussion of the extent to which utterances in Khwarizmian have the same value under Islamic law as utterances in Arabic. Composed around the $\mathrm{I}^{\text {th }}$ century $\mathrm{CE}$, they show a language still in wide daily use, albeit with much borrowing from Arabic and Persian. Though undoubtedly under pressure from both, Khwarizmian appears in the texts as a still-vital language with, for example, established strategies for integrating both Arabic and Persian loans: consider the abstract noun

\footnotetext{
${ }^{6}$ As it happens, Meyerhof's work on the foreword to al-Biruni's Pharmacology was nearly contemporary to Togan's discovery of Khwarizmian texts, as Meyerhof notes ('Das Vorwort der Drogenkunde des Beruni', I73).

${ }^{7}$ A. Zeki Velîdî Togan, 'Khwarezmische Sätze in einem arabischen Fiqh-werke', Islamica 3 (I927), pp. I902I3. It is essentially a critical edition of the parts of the 8 manuscripts discovered by Togan containing Khwarizmian glosses, though without translation. The sentences of this text were revisited by MacKenzie who gives a useful list of where they are repeated in the Qunya (David N. MacKenzie, 'Khwarizmian Enigma Variations', Bulletin of the Asia Institute Io (I996), pp. I4I-I47). For the Yatimat al-dahr see Carl Brockelmann, History of the Arabic Written Tradition, translated by Joep Lameer. Vol. I, (Leiden, 20I7), p. 4I3. This Yatima is not to be confused with al-Tha'ālibī's Yafīmat al-dahr fì mahăsin 'ahl al- 'aṣr from more than two centuries prior.

${ }^{8}$ Togan made Walter B. Henning aware of his discovery and the latter made a brief report on the language; see A. Zeki Velîdî Togan, 'Übern Sprache und Kultur der alten Chwarezmier', Zeitschrift der deutschen morgenländischen Gesellschaft 90 (1936), pp. ${ }^{*} 27^{*}-^{*} 30^{*}$ and Walter B. Henning, 'Über die Sprache der Chvarezmier', Zeitschrift der Deutschen Morgenländischen Gesellschaft 90 (I936), pp. * $30 *{ }^{*} 34^{*}$.

${ }^{9}$ Both the Qunya and the Risāla are preserved in a single manuscript in St. Petersburg which also contains other works of al-'Imādi. The Qunya part of this manuscript was copied in Rajab 754 / August I353 by a scribe named Kamāl b. 'Utmān b. Kamāl al-Harawī, while the Risāla part was copied on $4^{\text {th }}$ Rajab $755 / 26$ July I354 by "Ali b. Ab̄̄ Bakr b. Hamīe al-Ghūrī. This manuscript, which was copied from the author's autograph and corrected by him, forms the basis of MacKenzie's edition of the text, David N. MacKenzie, The Khwarezmian Element in the Qunyat al-munya (London, I996), pp. 3-6. For other manuscripts of the Qunya, not necessarily containing Khwarizmian, see Brockelmann, History of the Arabic Written Tradition, p. 4I4.
} 
hll'l'wk [halālāwak] meaning something like "halal-ness", derived from the Arabic word ḥalāl and the Khwarizmian nominal suffix -'wk [-āwak]. ${ }^{10}$

In the ${ }^{2} 3^{\text {th }}$ century, Khwarizm had long been under the rule of a succession of Turkic rulers and would be subjugated by the Mongols. Khwarizmian society was no doubt multilingual, with Arabic, Persian, and even Khwarizmian Turkic playing roles. The following extract from the Qunya illustrates how this text functions, how questions of language and law were considered, and the multilingual context of Khwarizm at that time. The passage first gives text in Khwarizmian (in Arabic script) and then proceeds to give an Arabic translation, as follows:

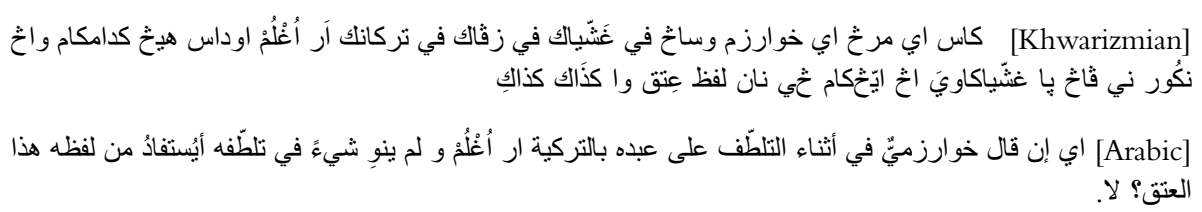

If a Khwarizmian man says "my brave lad" [är og $\mid u m]$ in Turkish to his slave in the course of pleasantry, and if through the pleasantry he has no intention [to manumit him] whatsoever, will manumission proceed from that word or not? No. ${ }^{11}$

The Arabo-Khwarizmian script has typically been transliterated rather than transcribed in publications by Iranists, and appears as follows in MacKenzie's edition of the text (short vowels are not written other than when indicated by the tašk $\bar{l}$, which is represented in superscript):

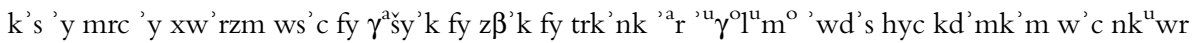

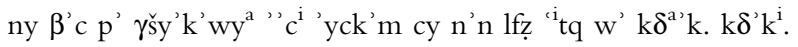

The second group of Khwarizmian source material is found in certain manuscripts of the Muqaddimat al-adab, the famed Arabic dictionary of al-Zamakhsharī (d. I I44), himself also a native of Khwarizm, which have interlinear glosses in Khwarizmian. Though it was long thought that the main manuscript was his autograph, it is more probable that it dates from around I200, nevertheless not long after the author's death. ${ }^{12}$ This material provides

${ }^{10}$ MacKenzie, The Khwarezmian Element in the Qunyat al-munya, p. I 3 .

${ }^{11}$ Qunya, passages I23-I25 (MacKenzie, ibid., pp. I7-I 8, 58, I88). For more about the style of these works see David N. MacKenzie, 'Khwarezmian in the Law Books', in Études Irano-Aryennes offertes à Gilbert Lazard (Paris, I989), pp. 265-276. By "Turkish" (bi-t-turkiyyati) is certainly not meant modern (Anatolian) Turkish but rather one of the Turkic languages or varieties that were current in $\mathrm{I} 3^{\text {th }}$-century Khwarizm.

${ }^{12}$ Togan published a facsimile of the manuscript, located in Konya, see A. Zeki Velîdî Togan, Documents on Khorezmian Culture, Pt. 1: Muqaddimat al-Adab, with the translation in Khorezmian / Horezm Kültürü Vesiklarn, Kisım 1: Horezmce tercümli Muqaddimat al-Adab (Istanbul, I95I). An edition was later given by Johannes Benzing, Das chwaresmische Sprachmaterial einer Handschrift der "Muqaddimat al-Adab" von Zamaxšari (Wiesbaden, I968), whose understanding of the Khwarizmian words was heavily critiqued by MacKenzie in a series of articles. Another copy of the Muqaddimat al-adab with Khwarizmian glosses was discovered in the I980s; it was copied, according to its colophon, in 797/I395 (Nuri Yüce \& Johannes Benzing, 'Chwaresmische Wörter und Sätze aus einer choresmtürkischen Handschrift der Muqaddimat al-Adab', Zeitschrift der deutschen morgenländischen Gesellschaft I 35, no. I (I985), pp. 92-I03). Henning had begun working on a Khwarizmian dictionary independently of Benzing but only the initial part was ready and was only published posthumously, Walter B. Henning, A Fragment of a Khwarizmian Dictionary, edited by D. N. MacKenzie (London, I97I). 
the majority of the known Khwarizmian lexicon with over 4,000 glosses, often individual words or brief phrases rather than sentences.

Taken together, all these sources shed light on Khwarizmian as it was written in the $12^{\text {th }}$ and ${ }^{2} 3^{\text {th }}$ centuries in the Arabic script. And indeed, the manuscripts' relative consistency in spelling and use of new letter-forms leads one to assume that they in fact are written in a roughly 'standard' Arabo-Khwarizmian script, even if later copyists did not always adhere to it or understand the Khwarizmian. And if, as al-Bīrūn̄̄ mentions, the Arab conquest ultimately led to the loss of knowledge of the indigenous script, it would be unsurprising if an Arabo-Khwarizmian one had developed soon after. Just as the Arabic script was extended to represent certain sounds required for Persian, such as $\underset{c}{ }$ for $[\check{c}]$ and $\Psi$ for $[\mathrm{p}]$, at some point it was also extended to represent Khwarizmian, in particular by the innovation of a new letter: $\dot{\vec{c}}$, a $h \bar{a}^{\prime}$ with three dots on top. ${ }^{13}$ This $\dot{\vec{c}}$ of the texts has been transliterated with a $c$ by Iranists, as can be seen in the above extract from the Qunya. This goes back to Henning, who proposed transliterating $c$ for $\dot{\tau}$ on the basis of both modern Pashto where the letter $\dot{z}$ represents [ts] and modern Ossetic in which Iranian ${ }^{*} \check{c}$ and ${ }^{*}$-ti- become [ts], a sound change which Henning proposed also for Khwarizmian. ${ }^{14}$ Later, Henning proposed that $c$ encodes both this $[\mathrm{ts}]$ and a voiced allophone $[\mathrm{dz}]$-also as in Pashto, where $\dot{\tau}$ was used for $[\mathrm{ts}]$ and $[\mathrm{dz}]$ from the late $17^{\text {th }}$ century until the $20^{\text {th }}$ century when the separate sign $\tau$ (a $h \bar{a}$ ' with hamza above) was developed for $[\mathrm{dz}]{ }^{15}$

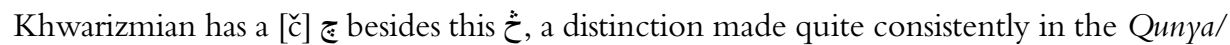
Risāla, though somewhat irregularly in the Muqaddima. ${ }^{16}$ The conditions under which both sounds occur have not been sufficiently clarified, however.

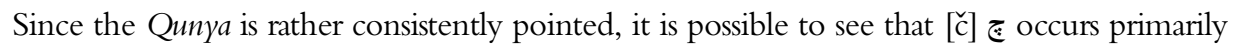
in Persian loanwords (such as $\check{c}$ ' $h$ 'pit' from Persian čāh) but also in inherited Khwarizmian words as a secondary change from earlier consonant clusters (such as '̌n 'to be thirsty' $<$ *tršn-). There are a handful of words written with $\check{c}$ where the $\check{c}$ may go back to Old Iranian *čc (such as crm 'skin' < *̌carman-, but this could also be a Persian loan), but the majority of words with older ${ }^{*} \check{c}$ are written with the $\dot{\mathcal{C}}$ (such as $\mathrm{cm}$ 'eye' $<{ }^{*}$ čašman- or $f f^{\prime} r$

\footnotetext{
${ }^{13}$ Khwarizmian also uses a fă ' with three dots above to represent [v], seemingly a distinct phoneme from [w]. This letter occurs also in very early New Persian manuscripts as a way of indicating $[\beta]$ since the $w \bar{a} w$ already indicated $[\mathrm{v}]$. It is thus not uniquely Khwarizmian, but the fact that they are shared is suggestive. For more on this letter and on the development of Arabo-Persian orthography in general, see now Paola Orsatti, 'Persian Language in Arabic Script: The Formation of the Orthographic Standard and the Different Graphic Traditions of Iran in the First Centuries of the Islamic Era', in Creating Standards: Interactions with Arabic Script in 12 Manuscript Cultures (Studies in Manuscript Cultures I6), (ed.) D. Bondarev, A. Gori, and L. Souag (Berlin, 2019), pp. 39-72.

${ }^{14}$ Henning 'Über die Sprache der Chvarezmier', p. * $3 \mathrm{I}^{*}$.

${ }^{15}$ Walter B. Henning, 'Mitteliranisch', in Handbuch der Orientalistik I.4.I (Leiden, I958), pp. 20-I30 [82]. The first attested use of $\dot{\vec{c}}$ for $[\mathrm{ts}]$ and $[\mathrm{dz}]$ in Pashto is from I697, whereas the earliest manuscripts (I65I-I690) employ $\dot{\tau}$ for [ts] and a dāl with subscript dot for [dz], cf. David N. MacKenzie, 'A standard Pashto', Bulletin of the School of Oriental and African Studies 22, no. I-3 (I959), pp. 23 I-235 [233]. In Pashto the affricates [ts] and [dz] derive from the depalatalisation of older $* \check{c}$ and $* \check{j}$, respectively. In Khwarizmian, older $*_{\mathfrak{j}}$ as well as ${ }^{2} \mathrm{z}$ seem to become $[\mathrm{z}]$.

${ }^{16}$ The manuscripts of the Muqaddima, particularly the one with the most extensive Khwarizmian glosses edited

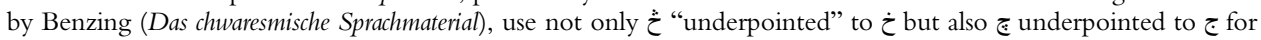
words which seem on the basis of their occurrence elsewhere or their etymology to have $\dot{\tau}$. This makes the task of establishing the possible difference between [ts] and [č in native Khwarizmian difficult. Additionally, a few words in

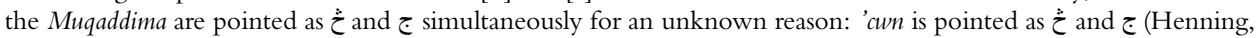
A Fragment of a Khwarizmian Dictionary, p. I3), and 'fc'wy is $\dot{\vec{c}}$ and (ibid., p. I6). Although the first of these is suggestive of an attempt at indicating a voiced sound, perhaps it is merely decorative as in the same manuscript simultaneous pointing is also found on ' $\delta r$ (one point under and one over the $d \bar{a} l), n m^{\prime} s r y$ ( $n$ and $\left.b\right)$, and $z w z(z$ and $z$ ).
} 


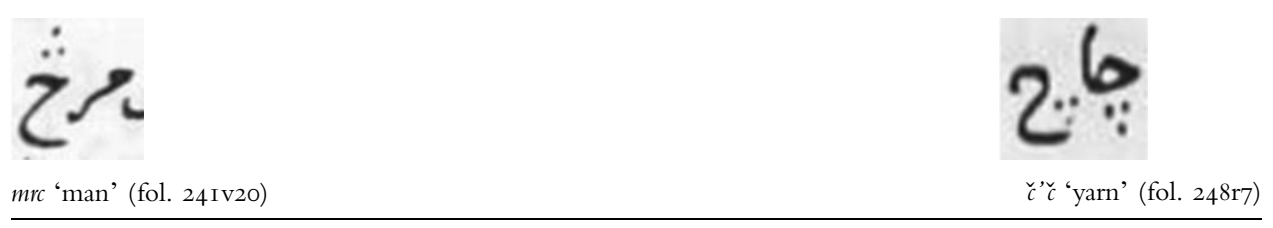

Table 2. Examples of palatalisation to $\mathrm{c}$ in Khwarizmian drawn from the Qunya and Muqaddima

\begin{tabular}{|c|c|c|}
\hline${ }^{*} \mathbf{t}>\mathbf{c}$ & ${ }^{*} \mathbf{k}>\mathbf{c}$ & $* \mathbf{d}>\mathbf{c}$ (mostly after $\left.{ }^{*} \mathrm{n} ?\right)$ \\
\hline *martiya- > mrc 'man' & pl. ${ }^{*}-\mathrm{ki}>-c(i)$ & *bandaya- $>\beta n c \gamma_{-}$'to tie' \\
\hline \multirow{3}{*}{${ }^{*}$ ati-iya- $>c y$ - 'to enter' } & *zānūki > z’nwi 'knees' & *pati-bandaya- $>p c \beta n c \gamma$ - 'to connect' \\
\hline & f.gen.sg. ${ }^{*}$-kiya $>-c(a)$ & \\
\hline & ${ }^{*} \gamma \bar{o}$ kiya $>\gamma w c^{a}$ 'of the cow' & \\
\hline
\end{tabular}

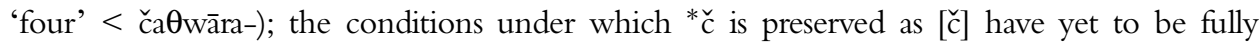
established. Several other sound changes in Khwarizmian have evidently led to $c$ being a frequently occurring letter: these include the palatalisation of ${ }^{*} \mathrm{t},{ }^{17}$ the palatalisation of ${ }^{*} \mathrm{k}$, and also seemingly the palatalisation of ${ }^{*} \mathrm{~d}$, in the environment of high vowels or the palatal glide [y].

As mentioned, it was words such as $\beta n c y$ which led Henning to suggest that $\dot{\vec{C}}$ not only encoded a voiceless affricate [ts] but also a voiced counterpart $[\mathrm{dz}]$ deriving from earlier ${ }^{*} \mathrm{~d}$; many if not most of these cases involve the sequence ${ }^{*}$-nd-, one of the few places where ${ }^{*} \mathrm{~d}$ did not change into a fricative $[ð]$ as it does elsewhere. We shall return to this discussion. In any case, this $\dot{\tau}$ seems to have been invented specifically for the needs of Khwarizmian and these manuscripts represent the earliest attestation of the letter $\dot{c}$, at least three centuries before it is used for Pashto for the first time. Yet when it was first used for Khwarizmian cannot be said with any certainty. Manuscripts of al-Bīrūn̄̄'s works in which he cites Khwarizmian terms do not employ the $\dot{\vec{c}}$, perhaps because they were copied by later, non-Khwarizmian-speaking scribes who did not know of the letter-in the Edinburgh manuscript (copied I307) of the Chronology, the ultimate source of Sachau's manuscripts, words with $c$ are written with either $ج$ or $₹$, and in the Beyazit manuscript, the oldest (I $2^{\text {th }}$ c.) and best manuscript of the Chronology, such words are written with either no points

\footnotetext{
${ }^{17}$ The palatalisation of $t[\mathrm{t}]$ to $c[\mathrm{ts}]$ does not seem to have taken place yet in the attested pre-Islamic Khwarizmian texts, or, if it had, the older writing system based on the Aramaic script did not represent the change after it had taken place in the spoken language. Moreover, it is worth pointing out, as MacKenzie already noted, that "there are many examples of differing developments of certain sounds, suggesting either a mixture of dialects or the adoption of loanwords from several neighbouring languages" (David N. MacKenzie, 'Chorasmia III: The Chorasmian Language' in Encyclopedia Iranica (online edition, I99I/20 I I), url: http://www.iranicaonline.org/articles/chorasmiaiii (last accessed 24 December 20I9). It is a possible scenario that the redactors of the ${ }_{1}{ }^{\text {th }}$-century texts gathered examples from informants from different areas with knowledge of different varieties.
} 
(ح) or just one (ج) $)^{18}$ —or because it had not been invented yet for the language. The earliest Khwarizmian source in Arabic script, the Konya manuscript of the Muqaddimat al-adab, does not appear until perhaps the end of the $\mathrm{I}^{\text {th }}$ century. But as with most ancient languages which are known today only in written form, it is difficult to know exactly how certain sounds were pronounced, and this $\dot{\vec{\tau}}$ is no exception. Fortunately, though, there exists a contemporary source potentially able to shed some light on the matter.

\section{Ibn Sīnā's Remarks on Khwarizmian}

Written between his arrival at the Iṣfahān court of 'Alā' al-Dawla in IO24 and his death in I037, Ibn Sīnā's treatise Asbāb Hudūt al-Hurūf (The Causes of the Genesis of the Consonants) gives a rigorous treatment of Arabic phonetics, detailing the various sounds in the Arabic language and the parts of the mouth involved in producing them. ${ }^{19}$ While the treatise draws on ancient traditions, especially Galen, it also contains unique and novel arguments about the physical production of sound, no doubt based on Ibn Sīnā's medical expertise. Several features of the work, from the order in which the letters are discussed to the linguistic terminology to several of the concepts (such as qal "sudden separation" and ruțūba "moisture"), set it apart from the classical Arabic linguistic traditions. ${ }^{20}$

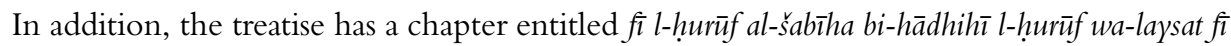
lughat al-" arab "Regarding consonants similar to these [Arabic] consonants but not in the language of the Arabs", ${ }^{21}$ in which are discussed both Arabic consonants which are produced incorrectly by non-Arabs, as well as sounds that were not part of Arabic but occurred in other languages with which he was familiar. His method involves comparing these sounds to the Arabic consonants he describes earlier in the treatise. For example, Ibn Sīnā notes that other languages have " " $\bar{g}$ im-like" consonants, "among them [being] the consonant which is pronounced at the beginning of the noun 'well' in Persian, which is čāh" (minhā

\footnotetext{
${ }^{18} \mathrm{My}$ thanks to François de Blois for the information about the pointing in these manuscripts; de Blois adds (personal communication) that pointing and vocalisation in the Edinburgh manuscript is largely decorative. Henning ('Mitteliranisch', 83) suggests that al-B̄̄rūnī employed an already-existing Arabic orthography for Khwarizmian in his Chronology, but I do not see how this can be proven.

${ }^{19}$ See Dimitri Gutas, Avicenna and the Aristotelian Tradition: Introduction to Reading Avicenna's Philosophical Works, 2nd edition (Leiden, 20I4), pp. 442-443, and Jules L. Janssens, An Annotated Bibliography on Ibn Sînâ (1970-1989) (Leuven, I99I), p. 49, for information about the extant manuscripts of the Asbāb Hudūt al-hurūf, sometimes known incorrectly under the title Makhärij al-hurūf. Gutas points out that as it was composed at the request of a philologist named Abū Manșūr Muḥammad al-Jabbān at the court of 'Alā' al-Dawla in Iṣfahān, it must have been composed after 4I5/I024. On Ibn Sīnā's time in Ișfahān, see Lenn Goodman, Avicenna (London, I992) pp. 3 off. The Causes has been edited several times and translated into English twice: Khalil Semaan, Arabic Phonetics. Ibn Sìnā's Risālah on the Points of Articulation of the Speech-sounds translated from Medieval Arabic (Lahore, 1963) only gives an English translation without commentary or Arabic text while Solomon Sara, A Treatise on Arabic Phonetics. Translation, Notes \& Comments (Munich, 2009) is a fuller study, including Arabic text and commentary. The Arabic text used in this article is that of Sara's edition-note that all translations from this text are mine with reference to Sara's translation.

${ }^{20}$ Important analyses of the theories which Ibn Sīnā develops behind these two terms are István Ormos, 'Observations on Avicenna's Treatise on Phonetics', Acta Orientalia Academiae Scientiarum Hungaricae 39, no. I (I985), pp. 45-84 and id., 'A Key Factor in Avicenna's Theory of Phonation', Acta Orientalia Academiae Scientiarum Hungaricae 40, no. 2-3 (I986), pp. 283-292. For other studies on this text not cited here, see Janssens, An Annotated Bibliography on Ibn Sînâ, pp. I53-I55.

${ }^{21}$ One version of the treatise has the shorter chapter title fi l-hurūfi l-šabìhati bi-hädhihī l-ḥurūf.
} 
l-harfu lladhī yunțaqu bihi fì auwali smi l-bi’r bi-l-färisiyyati wa-huwa čăh). ${ }^{22}$ Because of properties such as its place of articulation, Persian [č ], Ibn Sīnā notes, and correctly from a modern linguistic perspective, that it is similar to the Arabic [ $\check{\mathrm{g}}$ ]. He then states that there are other sounds which are not in Arabic or Persian but in other languages, such as a "șād-like" (sibh al-șàd) consonant and a "sinn-like" (sibh al-sinn) consonant, for which he neither specifies the language in which they occur nor gives any examples. He then goes on to describe a " $z \bar{a} y$-like $\sin$ that is frequent in the language of the people of Khwarizm" (sinun $z \bar{a}$ 'iyyatun taktaru fì lughati 'ahli khuwārizm). ${ }^{23}$

Before coming to a discussion of this sound, it is worth asking whether Ibn Sīnā was referring to that which we now know of as the Khwarizmian language, as opposed to a distinctive local variety of (New) Persian, since he says the "language of the people of Khwarizm" (lughat 'ahl khuwarizm) while the somewhat later sources discussed in the first part of this paper use "Khwarizmian" (khuwārizmī); these latter sources were, of course, written by actual speakers who no doubt knew what to call their own language, even in Arabic. Scholars of the generation just prior to Ibn Sīnā were aware of, or had encountered, a distinct language in the region, though for the most part they did not give it a specific name: the geographer al-Maqdisī (d. 99I) simply mentions that the "language of the people of Khwarizm cannot be understood" (lisän 'ahl khuwärizm là yufhim) ${ }^{24}$ while the noted traveller Ibn Faḍlān (d. 960) was somewhat more judgmental, writing in his travelogue that "the Khwarizmians are the most barbarous of people, both in speech and in custom. Their speech sounds like the cries of starlings (katāmuhum 'ašbaha šay' in bi-șiyahi $z$-zarāzir). There is a village... whose inhabitants are known as Kardaliya, and their speech sounds like the croaking of frogs (kalāmuhum 'ašbahu šay'in bi-naqīqi d-dafâdi )". ${ }^{25}$ Ibn Hawqal (d. ca. 978), who was in Khwarizm in 969, was more objective, stating that "[the Khwarizmians'] language is unique to them, no other like it is spoken in Khurāsān (wa-lisān 'ahlihā mufrad bi-lugatihim wa-laysa bi-khurāsān lisān 'alā lugiatihim)". ${ }^{26}$ So well before even al-Bīrūnī wrote about it, scholars of the time seem to have been aware of a particular and seemingly unique language in the region, and this general knowledge is likely to have been available to Ibn Sinnā.

More importantly, however, Ibn Sīnā spent about a decade, until ıо 2, living and working in Khwarizm at the court of the Khwarizm-Shāhs at Gurgānj, where he undoubtedly heard Khwarizmian being spoken and actually overlapped with al-Bīrūnī, with whom he also corresponded later in life. ${ }^{27}$ In fact, like his polymath colleague, Ibn Sīnā may also even have been a speaker of a non-Persian Iranian language before learning and mastering both Persian and Arabic. ${ }^{28}$ Given all this, it seems certain that Ibn Sīnā is indeed referring to the Khwarizmian language known to us.

\footnotetext{
${ }^{22}$ Sara, A Treatise on Arabic Phonetics, p. 37. Sara's commentary to this chapter of the work is quite brief and does not attempt to compare Ibn Sīnā's descriptions with data from the languages he alludes to (Persian and Khwarizmian).

${ }^{23}$ Sara, A Treatise on Arabic Phonetics, pp. 37-39, 72-73. Sara seems to be unfamiliar with the Khwarizmian language, calling it the "dialect of Khwarizm, area north east of Tehran" (ibid., p. I2 I).

${ }^{24}$ Basil Anthony Collins, translator, The Best Divisions for Knowledge of the Regions (Reading, 1994), p. 272

${ }^{25}$ Ibn Faḍlān, Risālat Ibn Faḍlān, edited by Sāmī Dahhān (Damascus, I959), p. 82.

${ }^{26}$ Ibn Hawqal, Kitāb șūrat al-ard, edited by J. H. Kramer (Leiden, I938), vol. 2, pp. 477-478, 48 I-482.

${ }^{27}$ For details of Ibn Sīnā's time in Khwārizm, see Goodman, Avicenna, pp. I9-24. Goodman refers to al-Bīrūnī, strangely, as a "Khwarizmian Persian".

${ }^{28}$ For Ibn Sinnā's background, see Goodman, Avicenna, I I. Sara (A Treatise on Arabic Phonetics, p. 36 n. 75 ) states that Ibn Sinā was a native speaker of Persian, but it would be surprising if in the late $10^{\text {th }}$ century the entire region
} 
Now, the entire passage to be discussed is as follows:

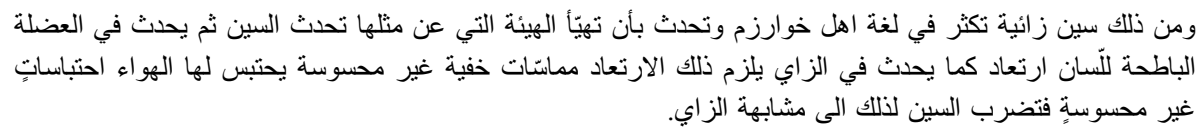

Among these [sounds not occuring in Arabic] is a $\sin z \bar{a}^{\prime} i y y a$ that is frequent in the language of the people of Khwarizm. It occurs by preparing the construction from the like of which the $\sin$ occurs, then in the flattening muscle of the tongue an irti 'ád occurs, as occurs with $z \bar{a} y$. That ${ }_{i r t i}$ ' $\bar{a} d$ is accompanied by hidden, imperceptible contacts, by which the air is trapped by imperceptible obstructions (ihtisābāt). Thereupon the $\sin$ occurs like the $z \bar{a} y .{ }^{29}$

How the $\bar{s} n$ and $z \bar{a} y$ are to be combined is at first glance difficult to envisage. Not so for the next sound described in the chapter, however, which is a šin-like $z \bar{a} y$ ( $z \bar{a} y$ šiniyya) of the kind, Ibn Sīnā says, heard in Persian when they say žarf 'deep' ( $z \bar{a} y u n$ šiniyyatun tusma 'u fì l-lughati l-färisiyyati 'inda qawlihim žarf). ${ }^{30}$ The point is quite clear: the zāy pronounced the place of articulation of the šin gives us [ž]. ${ }^{31}$ In modern linguistic terms, adding the voicing of the fricative $[\mathrm{z}]$ to the palato-alveolar articulation of the fricative [s] yields the voiced palato-alveolar fricative [ž]. Its writing with $j$ in the Arabo-Persian script, it is worth noting, likewise points to its association with Arabic $j$ rather than with $\underset{c}{\text {. But if a }[\check{s}]-l i k e ~}[z]$ is the sound $[z]$, then $[\mathrm{z}]-$ like $[\mathrm{s}]$ is not a new sound but simply remains $[\mathrm{z}]$. That is, adding of the voicing of $[\mathrm{z}]$ to $[\mathrm{s}]$ just gives $[\mathrm{z}]$. We might try to match the sound described in the Causes with what we already think we know of Khwarizmian from the sources previously mentioned. There are several $z \bar{a} y$-like and $\sin$-like sounds which are potential candidates for what Ibn Sinnā describes: besides [s] and [z] themselves, there are also [š] and [ž], as well as $[\check{c}]$ and the sound written by means of $\dot{\mathcal{c}}$. We can firstly eliminate $[\mathrm{s}],[\mathrm{z}]$, and $[\check{s}]$ from the list, as they, also occurring in Arabic, would not have merited any special comment by Ibn Sīnā. We can also eliminate [č since he describes that separately from the sin $z \bar{a}^{\prime}$ 'yya, as mentioned. What then could the sound be? Since Ibn Sīnā unfortunately cites no example from the Khwarizmian language, we must interpret his description of the consonants to determine what sound he understands this $\sin z \bar{a}^{\prime} i y y a$ to be. First is that the $\sin$ $z \bar{a}^{\prime} i y y a$ is based on the construction of the $\overline{s i n}$, the description of which is rather concise:

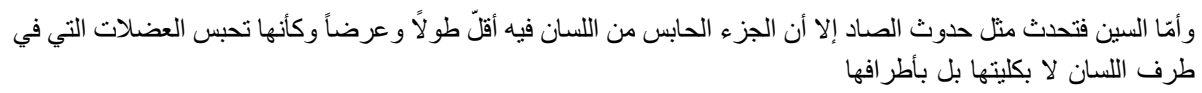

from Balkh to Bukhārā spoke only New Persian. In fact, al-Bīrūn̄i frequently cites words from "Bukhārān" (al-bukhāriyya) in his Pharmacology next to Sogdian and several other languages; the examples given suggest that "Bukhārān" was very close to, if not a variety of, Sogdian, cf. Henning, 'Mitteliranisch', p. 85. Al-Maqdisī also noted that the language of Sogdiana was similar to that of the rural districts of Bukhārā (wa-li-ṣ-șuggd lisān 'ala hida yuqāribuha alsinat rasātīq bukhārā), but his examples of Bukhārān speech seem to be simply Persian, cf. Collins, The Best Divisions for Knowledge of the Regions, p. 273.

${ }^{29}$ Sara, A Treatise on Arabic Phonetics, pp. 36-39, $72-73$.

${ }^{30}$ Ibid., pp. $38-39$.

${ }^{31}$ This method of describing a sound not occurring in Arabic, or at least not represented in the Arabic script, by citing two Arabic sounds which combine to yield something close to it may derive in part from an earlier work. Hamza al-Ișfahānī (d. after 96I), in his al-Tanbīh 'alā hudūt al-tashhịf, mentions several Persian consonants, such as

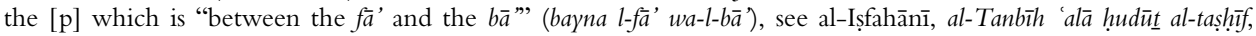
2nd edition, edited by Muhammad As'ad Țalas (Beirut, I992), pp. 34-35. Notably, his description of a few consonants corresponds to what is known of late Middle Persian or Early New Persian phonology. 
As for the $\bar{s} \bar{n}$, it occurs like the occurrence of the șad except that the obstruction (habs) of the tongue in it is less in length and in width. It is as though the muscles that are at the edge of the tongue obstruct (tahbis) not with their entirety but with their edges. ${ }^{32}$

The $\sin$ is thus related to the șâd in terms of its "obstruction" (habs), but is said to be less (aqall) and to not involve the entirety of the tongue. If we turn to the șâd, we find that it is likewise described in relation to the $\sin$, where it is said to have a "narrower" (adyaq) and "drier" (aybas) obstruction than the $\sin$ but that it covers ( $y u t b i q)$ two-thirds of the surface of the palate. If Ibn Sīnā's description of the $\sin$ is brief, though, then his description of the $z \bar{a} y$ is much more long and complicated, but worth citing in full:

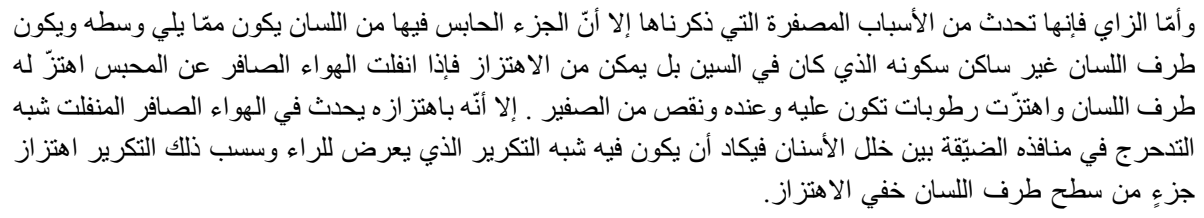

As for the $z \bar{a} y$, it occurs from the whistling causes that we mentioned except that the habs of the tongue emerges near its middle and the edge of the tongue is not holding the stationary position that occurs in the [articulation of the] $\sin$, but is, rather, capable of ihtizāz. If the whistling air escapes the place of obstruction (mahbas), the edge of the tongue vibrates (ahtazza) to it; the moistures that it has and that are on it vibrate (ahtazzat) and it has a diminishment of the whistling, except that in its ihtiza $z$ it causes in the whistling and coursing air a quasi-tumble in its narrow passages between the gaps of the teeth. There is in it almost the quasi-repetition that happens to the $r \bar{a}$ ' and the cause for that repetition is the ihtiza $z$ of a part of the surface of the edge of the tongue with a hidden ihtizā $z{ }^{33}$

The first way in which the $\sin z \bar{a}^{\prime} i y y a$ is then $z \bar{a} y$-like is that, according to its description, "in the flattening muscle of the tongue an irti 'âd occurs, as occurs with zāa" ( yah l- 'adalati l-bātihhati li-l-lisāni kamā yahduț fi l-zāy). The description of the $z \bar{a} y$, however, mentions no irti ' $\bar{a} d$, which I have left untranslated for the moment. Instead, the $z \bar{a} y$ is described as differing from $\sin$ with regards to ihtiz $\bar{a} z$ : "the edge of the tongue is not holding the stationary position that occurs in the [articulation of the] $\sin$ but is, rather, capable of ihtizāa"

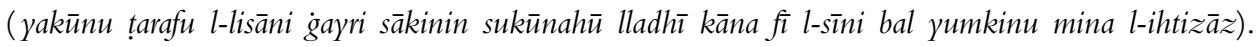
The related consonant zāy šniyya [ž] is also described as "manifested by the ihtizāa of the surface of the tip of the edge of the tongue" (tu 'ridu bi-htizāzi sathi țarafi l-lisān). So, to the $z \bar{a} y$ itself and the $\check{s i n}$-like $z \bar{a} y$, Ibn Sinna ascribes the characteristic of ihtizāa, which he only uses for the small group of consonants presented in Table 3 below.

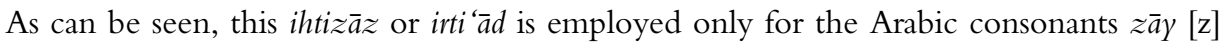
and $\underline{d} \bar{a} l[ð]$, and for several non-Arabic consonants such as the " $f \bar{a}$ ' which almost resembles

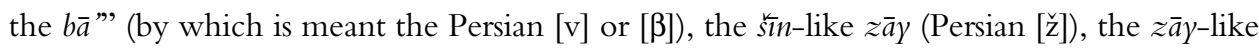
$\sin$ of Khwarizmian, and a $z \bar{a}$ '-like $z \bar{a} y$ in an unspecified non-Arabic language. Ibn Sinnā only otherwise uses the term in the description of the $\dot{g} a y n$, where he says the airflow causes something similar to ihtizāz (but not ihtizāz itself). Since the description mostly uses ihtizāa,

\footnotetext{
${ }^{32}$ Sara, A Treatise on Arabic Phonetics, pp. $30-3 \mathrm{I}$.

${ }^{33}$ Sara, A Treatise on Arabic Phonetics, pp. 30-3 I.
} 
Table 3. Consonants to which Ibn Sīnā ascribes ihtizāz or irti 'ād

\begin{tabular}{|c|c|c|}
\hline Consonant & Description & Translation \\
\hline$z \bar{a} y$ & $\begin{array}{l}\text { yakūnu țarafu l-lisāni gayri sākinin sakūnahū lladi } \\
\text { kāna fí s-sīn bal yumkinu mina l-ihtizāz }\end{array}$ & $\begin{array}{l}\text { "the edge of the tongue is not holding the } \\
\text { stationary position that occurs in the } \\
\text { [articulation of the] } \sin \text { but is, rather, capable } \\
\text { of ihtizā } z "\end{array}$ \\
\hline$\underline{d} \bar{a} l$ & 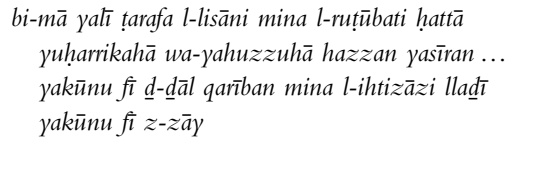 & 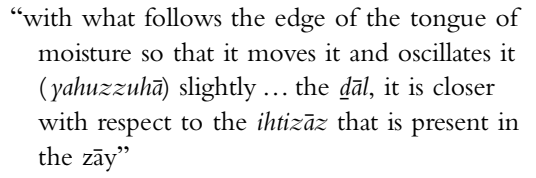 \\
\hline $\sin z \bar{a}^{\prime} i \gamma \gamma a$ & 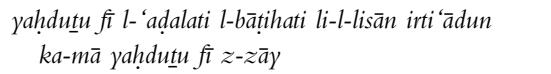 & $\begin{array}{l}\text { "an irti ad occurs in the flattening muscle of the } \\
\text { tongue like that which occurs in the } z \bar{a} y "\end{array}$ \\
\hline$z \bar{a} y$ šninyya & wa-hiya š̃nun ... ta 'ridu bi-htizāzi sathi țarafi l-lisān & $\begin{array}{l}\text { "it is a } s \bar{i} n \text {... manifest by an ihtizā } z \text { of the surface } \\
\text { of the edge of the tongue" }\end{array}$ \\
\hline$z \bar{a} y z^{\prime} \bar{a}^{\prime} i y y a$ & $\begin{array}{l}\text { yakūnu wasațu l-lisāni fìhā 'arfa'a wa-l-ihtizāzu fì } \\
\text { țarafi l-lisāni xafiyyun jiddan }\end{array}$ & 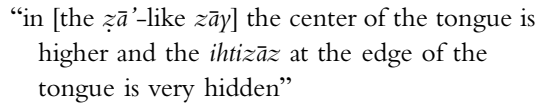 \\
\hline $\begin{array}{l}\text { fáa' tukād } \\
\text { tuśbahu } l-b \bar{a} \text {, }\end{array}$ & 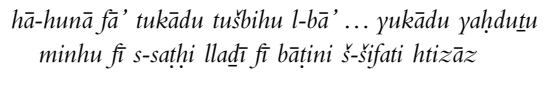 & 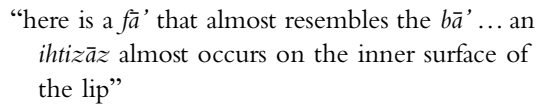 \\
\hline
\end{tabular}

and only once irti ' $\bar{a} d$ (which is linked to the $z \bar{a} y$ where ihtizāz is used), it is possible that both terms are meant to refer to the same phenomenon. In particular, this seems to be a characteristic of what we would now call voiced fricatives. Though in 2009 Sara translated ihtizāz as "oscillation" but irti 'âd as "trembling", implying a difference in the two, I think that on the basis of their usage and the similarities in the consonants grouped above, it is reasonable to assume that Ibn Sinna intended them to describe the same phenomenon. ${ }^{34}$ As a property common to voiced fricatives, both terms may best be translated with "vibration". Yet in general the Causes does not make use of a category comparable to our modern category of "voice". Instead, by using "vibration", the treatise tends to point to where vibration, as an effect of voiced consonants, can be felt in the mouth: for $[\mathrm{z}]$ and $[\partial]$ it is on the "edge of the tongue" (tarafi l-lisān) while for the sin za' 'iyya it is in the "flattening muscle of the tongue" (al- "adalati al-batihati li-l-lisān), for the [ž $]$ it is on the "surface of the edge of the tongue" (sațhi tarafi l-lisān), and for the $[\mathrm{v}]$ or $[\beta]$ it almost occurs on the "inner (surface) of the lip" (bātini šs-sifati).

The second characteristic of the $\sin z \bar{a}$ ' $i y y a$ is that the airflow is trapped by "imperceptible obstructions" (ihtisäbāt gayr mahsūsa). The feature of "obstruction" (habs) occurs frequently in the work and appears to be a fundamental feature of Ibn Sīnā's phonetic description. Habs is used to describe how and where oral elements touch each other to change the airflow and produce different sounds: this could be the tongue touching the palate (as in the $s \bar{a} d$ ), but could also be both lips touching each other (as in the $b \bar{a}$ '). Many consonants have a "complete obstruction" (ḥabs tāmm), some have an "incomplete obstruction" (habs gayr tāmm), and

${ }^{34}$ Ormos ('Observations on Avicenna's Treatise on Phonetics') points out that the terminology used by Ibn Sīnā in this work is not entirely systematic and consistent, though he does not mention ihtizāz specifically. 
others, interestingly enough, are described as having no habs, in particular the šn, which is said to be like the jim but with no obstruction at all. ${ }^{35}$ Since the habs is what is involved in obstructing the oral cavity, it does not just have quantity ("complete" or "incomplete") but also quality: as we have seen it may be "less" (aqall) as in the $\sin$ or "drier" (aybas) as in the $s \bar{a} d .^{36}$

Do these descriptions help us to understand the articulation of the $\sin z \bar{a}^{\prime}$ iy $y a$ ? First, it is related to the $\bar{s} \bar{n}$ (and thereby also to the $s \bar{a} d$ ) in the quality and quantity of its habs. This suggests that among obstruents, it belongs towards the fricative (including [s] but excluding $[\mathrm{s}])$ to affricate side of the consonant group (the only affricate in Ibn Sīnā's system seems to be [j]]). Secondly, it has "vibration" like the $z \bar{a} y$ and other voiced fricatives. Ibn Sīnā's system thus suggests that the $\sin z \bar{a}^{\prime} i y y a$ is a voiced alveolar sibilant fricative or affricate.

As mentioned previously, Iranistic scholarship has postulated the sounds [ts] and [dz] for Khwarizmian, both encoded by the Arabic letter $\dot{\vec{c}}$. If our analysis of Ibn Sīnā's description of the $\sin z \bar{a}^{\prime} i y \gamma a$ is correct, then the best match for it seems to be [dz] rather than [ts]. From the perspective of our understanding of the Khwarizmian sources, this is somewhat unexpected, as [ts] seems to be the more common sound, at least on the basis of etymology. One possibility is that what has been thought thus far to be a [ts] was actually a voiced $[\mathrm{dz}]$, and this $[\mathrm{dz}]$ was therefore one of the most prominent "foreign" sounds to an Arabic or Persian ear. It seems odd that Ibn Sīnā, with his firsthand knowledge of Khwarizmian and ability to describe both differing pronunciations of Arabic sounds such as $q \bar{a} f^{37}$ and nonArabic sounds such as the [p], [v], [̌c], and [ž] of Persian, would not have been able to notice both a [ts] and a [dz], if both existed. But his treatise on phonetics does not cover all the possible sounds he could have heard in the various languages spoken in the places he lived; perhaps a $[\mathrm{dz}]$ was more unusual to him than other sounds and therefore merited description. $^{38}$

At the same time, Ibn Sīnā does not claim to exhaustively describe all non-Arabic sounds he had ever heard, and does not consistently give examples for those which he does describe. It thus seems that the section on non-Arabic sounds in the Causes most likely served to give further examples illustrating the applicability of his phonetic approach to speech sounds in general. Ibn Sīnā's remarks do not, unfortunately, bring a definitive solution to our study of this aspect of Khwarizmian phonology. It is nevertheless my contention that he was

\footnotetext{
${ }^{35}$ Sara, A Treatise on Arabic Phonetics, p. 29.

${ }^{36}$ See Sara, ibid., pp. 90-92 for more discussion of habs in this work. In fact, it corresponds quite closely to what we would call "obstruents", a category based on whether speech sounds obstruct airflow.

${ }^{37}$ See Haïm Blanc, 'Les deux prononciations du qāf d'après Avicenne', Arabica I3, no. 2 (I966), pp. I29-I36, who attempts to connect the two pronunciations of $q \bar{a} f$ in the Causes to modern Arabic dialects.

${ }^{38} \mathrm{It}$ is an intriguing but perhaps unlikely possibility that șâd was still pronounced as an affricate in Ibn Sīnā's time and that he therefore would not have thought a voiceless affricate unusual in Khwarizmian vis-à-vis Arabic but would have noticed a voiced one; Ahmad Al Jallad ("Așsṣādu llatī ka-s-sīn: evidence for an affricated șād in Sibawayh?', Folia Orientalia 5I (20I4), pp. 5I-57) has recently argued that șād was still an affricate [tṣ] at the time of Sibawayh, but this is two centuries before Ibn Sīnā. From the description of the șâd in the Causes, it is difficult to tell if Ibn Sīnā is describing an affricate. The key phrase may be "the air escapes from that madīq after a great

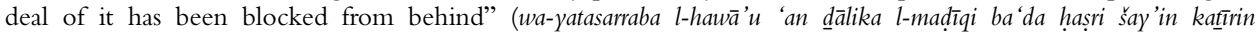
min-hu min wara') (see Sara, A Treatise on Arabic Phonetics, pp. 28-3I), but the phrase is ambiguous in that it employs hașr, a term otherwise not occurring in the text, perhaps for habs, and in that it could simply be describing the fact that the raised tongue restricts the oral cavity a great deal, especially in comparison with the $\sin$, to which it is related in the Causes.
} 
describing a real sound present in the Khwarizmian language of his day, and quite possibly the sound, or one of the sounds, encoded by the Arabic letter $\dot{\tau}$, developed specially for writing Khwarizmian. What scholars reconstruct of the phonology of a medieval language preserved only in written texts is, of course, tentative. It is thus instructive to consider examples, rare as they may be, of linguistic analysis of such languages dating from a time in which they were still spoken. That the two may not neatly agree is an invitation both to revisit our understanding of those texts and to continue to cast our nets wider in search of contemporary sources.

\author{
Adam Benkato \\ University of California, Berkeley \\ abenkato@berkeley.edu
}

